\title{
STUDI KOMPARATIF PENGARUH KUALITAS PELAYANAN TERHADAP KEPUASAN NASABAH (PT. BPR. Mertha Sedana dan PT. BPR. Mas Giri Wangi)
}

\author{
Kadek Ari Dwi Divayana ${ }^{1}$ \\ Gede Bayu Rahanatha ${ }^{2}$ \\ ${ }^{1,2}$ Fakultas Ekonomi dan Bisnis Universitas Udayana (Unud), Bali Indonesia \\ email : kadekari.divayana@gmail.com
}

\begin{abstract}
ABSTRAK
Penelitian ini bertujuan untuk mengetahui perbandingan pada pengaruh kualitas pelayanan terhadap kepuasan pada nasabah PT. BPR. Mertha Sedana dan PT. BPR. Mas Giri Wangi. Penelitian melibatkan 2 Bank Perkreditan Rakyat yang memiliki kesamaan pada permodalan namun berlokasi di tempat yang berbeda. Analisis regresi linier berganda digunakan sebagai teknik analisis data. Teknik pengambilan sampel yang digunakan dalam penelitian ini adalah Purposive Sampling. Purposive sampling adalah penentuan sampel dengan pertimbangan tertentu sehingga kriteria yang digunakan dalam menentukan sampel berupa pendidikan terakhir minimal SMA, merupakan nasabah pada BPR terkait, dan pernah melakukan transaksi pada BPR terkait. Jumlah responden yang terlibat pada masing - masing BPR adalah 65 orang sehinga total keseluruhan responden yang terlibat adalah 130 orang. Berdasarkan hasil pengujian hipotesis menunjukkan variabel bukti fisik, keandalan, daya tanggap, jaminan dan empati berpengaruh terhadap variabel kepuasan nasabah baik nasabah PT. BPR. Mertha Sedana dan PT. BPR. Mas Giri Wangi. Hasil yang ditemukan adalah kualitas pelayanan yang terdiri dari bukti fisik, keandalan, daya tanggap, jaminan dan empati berpengaruh positif dan signifikan terhadap kepuasan nasabah pada kedua BPR. Empati merupakan variabel yang paling dominan mempengaruhi kepuasan pada nasabah PT. BPR. Merttha Sedana, sedangkan keandalan merupakan variabel yang paling dominan mempengaruhi kepuasan nasabah PT. BPR Mas Giri Wangi.
\end{abstract}

Kata kunci:bank perkreditan rakyat (BPR), kualitas pelayanan, kepuasan nasabah.

\begin{abstract}
This study aimed to compare the effect of service quality on customer satisfaction of PT. BPR. Mertha Sedana and PT. BPR. Mas Giri Wangi. The study involved 2 kinds of Bank which has similarities to the capital but both of them are located in different places. Multiple linear regression analysis was used as a data analysis technique. The sampling technique used in this research is purposive sampling. Purposive sampling is sampling with particular consideration to the criteria used in determining the final sample of at least high school education, customers of the relevant BPR and conduct a transaction on related $B P R$. The number of respondents involved in each - each BPR is 65 so that the total respondents involved is 130 people. Based on the results of hypothesis testing showed variable physical evidence, reliability, responsiveness, assurance and empathy effect on customer satisfaction variables both customers of PT. BPR. Mertha Sedana and PT. BPR. Mas Giri Wangi. Results are the quality of services consisting of physical evidence, reliability, responsiveness, assurance and empathy positive and significant impact on customer satisfaction in both of BPR. Empathy is the most dominant variable influence on customer satisfaction PT. BPR. Mertha Sedana, while reliability is the most dominant variable affecting customer satisfaction PT. BPR. Mas Giri Wangi.
\end{abstract}

Keywords: bank perkreditan rakyat (BPR), service quality, customer satisfaction. 


\section{PENDAHULUAN}

Dewasa ini orang dapat bertahan hidup dengan keberadaan perekonomian, perekonomian bisa dipengaruhi oleh banyak faktor baik berasal dari faktor budaya, politik, sumber daya manusia, sumber daya alam, maupun lokasi. Semua faktor tersebut memiliki hubungan yang saling terkait. Maju atau mundurnya suatu daerah itu dapat ditentukan oleh majunya perekonomian di suatu daerah. Semakin jauh daerah tersebut dari kota, maka semakin rendah perekonomian masyarakat setempat. Hal itudapat dipengaruhi oleh biaya transportasi yang lebih tinggi sehingga harga jual dari barang tersebut relatif lebih mahal dan relatif tidak bisa dijangkau oleh masyarakat setempat sehingga perekonomian mengalami penurunan.

Pada dasarnya untuk mengoptimalkan perekonomian di suatu daerah, pemerintah mengoptimalkan lembaga-lembaga keuangan seperti koperasi, lembaga perkreditan desa, bank perkreditan rakyat, dan perbankan. Di negaranegara seperti Indonesia, peranan bank cenderung penting dalam pembangunan karena bukan hanya sebagai sumber pembiayaan untuk kredit investasi kecil, menengah, dan besar tetapi juga mampu mempengaruhi siklus usaha dalam perekonomian secara keseluruhan (Setyari,2007). Bank Perkreditan Rakyat (BPR) yang merupakan salah satu lembaga perbankan yang dikenal di Indonesia, diatur dalam ketentuan Pasal 5 ayat (1) Undang-Undang No.7 tahun 1992 tentang Perbankan.Seperti yang telah direfisipada UU No.10 tahun 1998 menyatakan bahwa bank adalah badan usaha yang menghimpun dana dari masyarakat dalam bentuk simpanan dan menyalurkannya kepada masyarakat dalam bentuk kredit 
dan atau bentuk-bentuk lainnya dalam rangka meningkatkan taraf hidup rakyat banyak. Bank dapat dibagi dalam dua jenis yaitu Bank Umum dan Bank Perkreditan Rakyat. Bank Perkreditan Rakyat adalah bank yang melaksanakan kegiatan usaha secara konvensional dan atau berdasarkan prinsip syariah yang dalam kegiatannya tidak memberikan jasa dalam lalu lintas pembayaran, sedangkan Bank Umum adalah bank yang melaksanakan kegiatan usaha secara konvensional dan atau berdasarkan prinsip syariah yang dalam kegiatannya memberikan jasa dalam lalu lintas pembayaran.

BPR merupakan salah satu lembaga keuangan bank yang diharapkan mampu memberikan fasilatas baik berupa pinjaman maupun penyimpanan uang. BPR diharapkan mampu memberikan solusi bagi orang yang ingin membuka usaha khususnya usaha bertaraf menegah ke bawah. Karena dengan tingkat bunga yang sangat kompetitif, masyarakat diharapkan bisa mengoptimalkan keberadaan suatu bank perkreditan rakyat atau BPR. Dalam mengoptimalkan keberadaan suatu bank perkreditan rakyat atau BPR tentu hal ini akan membantu pengusaha baik dari segi permodalan usaha-usaha mereka, agar pengusaha dapat membuat, mengembangkan serta mempertahankan bisnis mereka. Oleh karena berkembangnya baik dari segi kuantitas maupun kualitas, mereka akan melibatkan banyak orang dalam mendirikan usaha-usaha mereka sehingga secara tidak langsung perekonomian masyarakat setempat meningkat.

Seiring berkembangnya jaman banyak pemodal mendirikan lembagalembaga keuangan salah satunya adalah BPR serta memiliki tujuan yang hampir sama,yakni untuk meningkatkan perekonomian masyarakat sekitar. Adapun data 
statistik mengenai jumlah BPR konvensional berdasarkan badan hukum di Provinsi Bali periode November 2016 yang di publikasikan oleh Bank Indonesia adalah sebagai berikut:

Tabel 1.

Jumlah BPR Konvensional Berdasarkan Badan Hukum di Provinsi Bali Periode November 2016

\begin{tabular}{llccc}
\hline No & \multicolumn{1}{c}{ Provinsi } & PT & PD & Jumlah BPR \\
\hline 1 & Kab. Badung & 52 & 0 & 52 \\
2 & Kab. Bangli & 2 & 1 & 3 \\
3 & Kab. Buleleng & 6 & 1 & 7 \\
4 & Kab. Gianyar & 27 & 1 & 28 \\
5 & Kab. Jembrana & 1 & 0 & 1 \\
6 & Kab. Karangasem & 4 & 0 & 4 \\
7 & Kab. Klungkung & 5 & 0 & 5 \\
8 & Kab. Tabanan & 24 & 0 & 24 \\
9 & Kota Denpasar & 13 & 0 & 13 \\
10 & Kab./ Kota lainnya & 0 & 0 & 0 \\
\hline \multicolumn{2}{l}{ Total } & 134 & 3 & 137 \\
\hline
\end{tabular}

Dari data yang telah dipublikasikan oleh BI, jumlah BPR yang terbilang banyak ini dan juga perkembangan yang semakin pesat maka BPR berlombalomba mencari perhatian di masyarakat dengan harapan masyarakat dapat menggunakan fasilitas-fasilitas yang tersedia di BPR. Masing-masing BPR memiliki strategi tersendiri untuk meraih perhatian masyarakat sekitar, misalkan dengan cara memberikan point, hadiah pengundian bagi nasabah dengan jumlah tabungan tertentu serta memberikan kemudahan-kemudahan di dalam melakukan transaksi. Fasilitas-fasilitas diatas seperti pembayaran listrik, air, asuransi, dan cicilan bisa melalui BPR sehingga masyarakat bisa menggunakan fasilitas-fasilitas BPR di sekitar tempat tinggal mereka. Fasilitas-fasilitas itu ternyata juga mampu meningkatkan penghasilan BPR. Dilain pihak BPR mengoptimalkan pelayananpelayanan yang diberikan kepada nasabah. 
Salah satu BPR yang terletak di Kabupaten Badung adalah PT. BPR. Mertha Sedana. PT. BPR. Mertha Sedana berada di Jalan Denpasar-Tabanan, Mengwitani, Mengwi Badung. PT. BPR. Mertha Sedana juga menawarkan beberapa produk seperti tawaran tabungan, kredit, deposito dan juga pembayaranpembayaran seperti tagihan listrik, telpun, air dan juga pembayaran asuransi.

Salah satu BPR yang berada di Kabupaten Gianyar adalah PT. BPR. Mas Giri Wangi yang berlokasi di Jalan Udayana Blahbatuh Gianyar. PT. BPR. Mas Giri Wangi juga menawarkan beberapa produk seperti tabungan, deposito, kredit dan juga pembayaran-pembayaran lainnya. PT. BPR. Mas Giri Wangi juga memiliki strategi-strategi untuk memenuhi dan juga memuaskan para nasabahnya.

Kedua BPR ini tentu memiliki sumber daya yang berbeda dan juga memiliki keunggulan kompetitif yang dapat membedakan kedua BPR tersebut dari pesaingpesaingnya, tetapi didalam penelitian ini, kedua BPR ini memiliki beberapa kesamaan yang dapat diperhitungkan untuk mengukur kualitas pelayanan terhadap kepuasan nasabah diantaranya kedua BPR ini memiliki kesamaan yakni dari segi pengawasan (komisaris) yang sama, dimana komisaris ini merupakan seseorang atau sekelompok orang yang dipilih atau ditunjuk sebagai pengawas dimana tujuannya untuk mengawasi kegiatan-kegiatan yang ada di suatu perusahaan itu sendiri. Untuk kedua BPR ini baik dari segi komisaris memiliki kesamaan. Dilihat dari segi permodalan, kedua BPR ini juga hampir memiliki kesamaan sehingga cocok untuk dijadikan perbandingan anatara kedua BPR ini karena memiliki kelas yang sama dibandingkan dengan BPR lainnya. Keadaan kedua BPR ini juga 
memiliki kondisi yang sama atau dapat dikatakan sehat karena tercermin dari data yang diperoleh dari kedua BPR yakni:

Tabel 2.

Kondisi Kesehatan PT. BPR. Mertha Sedana dan PT. BPR. Mas Giri Wangi

\begin{tabular}{ccccc}
\hline No. & Bank & \multicolumn{2}{c}{ Rasio (\%) } & Predikat \\
\hline 1. & PT. BPR Mertha Sedana & CAR & 14,08 & Sehat \\
& & LDR & 81,07 & Sehat \\
& & ROA & 2,88 & Sehat \\
2. & PT. BPR Mas Giri Wangi & CAR & 22,72 & Sehat \\
& & LDR & 81,25 & Sehat \\
& & ROA & 4,01 & Sehat \\
\hline \multicolumn{2}{l}{ Sumber : PT. BPR. Mertha Sedana dan PT. BPR. Mas Giri } & Wangi, 2017
\end{tabular}

Dari keterangan Surat Edaran Bank Indonesia No 6/23/DPNP Tahun 2004 menyatakan bahwa bank dikatakan sehat apabila CAR $>9 \%$, sedangkan untuk LDR (Loan to Deposit Ratio) suatu bank dikatakan sehat apabila LDR > 75\% dan untuk ROA (Return On Asset) suatu bank dikatakan sehat apabila ROA > 1,25\%. Maka dapat disimpulkan untuk kondisi kedua BPR tersebut berada dalam predikat sehat dan dapat untuk dilakukan perbandingan.

Seiring dengan kondisi lingkungan bisnis yang bersaing ini tentu perusahaan dan lembaga keuangan lainnya dituntut untuk memberikan pelayanan yang baik terhadap para nasabahnya. Persaingan yang semakin ketat ini membuat beberapa perusahaan seperti perbankan senantiasa harus meningkatkan kualitas pelayanan agar nasabah merasa nyaman dan percaya yang nantinya mengakibatkan tidak mudahnya nasabah tersebut berpindah pada lembaga keuangan lainnya. Menurut Jaman (2009) menyatakan bahwa agar nasabah tidak mudah untuk berpindah, maka kualiatas pelayanan yang diberikan harus lebih baik dan unggul dari pada dengan perusahaan lain atau perbankan lainnya. Dengan membangun dan memiliki hubungan yang baik dengan nasabah maka hal tersebut sangatlah penting untuk dilakukan dalam perbankan. Menurut Ariyani (2010), kualitas 
pelayanan sangatlah penting dalam bisnis perbankan. Selain menawarkan berbagai macam produk, perbaikan disisi teknologi informasi, pelayanan fisik, dan pelayanan non fisik dimaksudkan untuk meningkatkan kualitas pelayanan.Yonggoi (2004:125) menyatakan bahwa bagi suatu perusahaan khususnya perusahaan jasa, kualitas pelayanan sangat mempengaruhi tingkat kepuasan pelanggan. Kualitas pelayanan yang diberikan oleh lembaga keuangan seperti bank perkreditan rakyat (BPR) akan bergantung pada loyalitas dari para nasabahnya. Menurut Regan (2009) menyatakan bahwa kepuasan pelanggan merupakan suatu tingkatan dimana kebutuhan, keinginan dan harapan pelanggan dapat terpenuhi yang nantinya akan mengakibatkan pembelian kembali atau kesetian yang berlanjut. Pelanggan dalam artian ini adalah para nasabah khususnya pada perbankan.Kepuasan nasabah merupakan suatu ungkapan seseorang dalam memberikan nilai atau mengoptimalkan nilai yang dirasakan dan diharapkan seseorang terhadap suatu produk atau jasa (Hadiati, 2004:300). Memberikan layanan yang berkualitas tinggi adalah suatu keharusan untuk mencapai kepuasan pelanggan (Bedi, 2010). Penilaian masyarakat terhadap lembaga keuangan seperti bank perkreditan rakyat dipengaruhi oleh bagaimana masyarakat memaknai produk bank atau pelayanan yang diberikan oleh bank tersebut. Parasuraman et al. (1998) menjelaskan bahwa produk jasa tidak dapat dinilai seperti produk barang karena sifat dari produk jasa itu sendiri adalah abstrak dan sulit untuk di pahami. Oleh karena itu kualitas pelayanan memiliki peran yang penting bagi produk jasa, karena kualitas pelayanan berperan penting untuk menarik pelanggan dan mempertahankan pelanggan. 
Dari keterangan dan informasi yang didapat dari kedua BPR makapeneliti sangat tertarik untuk meneliti kualitas pelayanan pada kedua BPR diatas. Kebaharuan dalam penelitian ini adalah penelitian ini belum pernah dilakukan oleh peneliti sebelumnya yang berfokus pada studi komparatif pada kualitas pelayanan di PT. BPR. Mertha Sedana dan PT. BPR. Mas Giri Wangi. Penelitian sebelumnya juga kebanyakan berasal dari luar negri yang melakukan penelitian mengenai studi komparatif kualitas pelayanan pada bank nasional dan bank swasta.

Dari latar belakang yang telah dipaparkan, maka rumusan masalah dalam penelitian ini adalah apakah kualitas pelayanan berpengaruh positif dan signifikan terhadap kepuasan nasabah PT. BPR. Mertha Sedana dan PT. BPR Mas Giri Wangi, dan variabel manakah dari kualitas pelayanan yang terdiri dari bukti fisik (tangibles), keandalan (reliability), daya tanggap (responsiveness), jaminan (assurance) dan empati (empathy) yang memiliki pengaruh dominan terhadap kepuasan nasabah pada PT. BPR. Mertha Sedana dan PT. BPR. Mas Giri Wangi. Berdasarkan pada rumusan masalah tersebut, maka tujuan penelitian adalahuntuk mengetahui pengaruh kualitas pelayanan terhadap kepuasan nasabah PT. BPR. Mertha Sedana dan PT. BPR. Mas Giri Wangi, dan untuk mengetahui variabel manakah dari kualitas pelayanan yang memiliki pengaruh dominan terhadap kepuasan nasabah PT. BPR. Mertha Sedana dan PT. BPR. Mas Giri Wangi.

Penelitian ini mempunyai dua kegunaan yaitu kegunaan teoritis dan kegunaanpraktis. Kegunaan teoritis berupa penelitian ini nantinya diharapkan dapat memberikan kontribusi empiris mengenai kualitas pelayanan bagi 
pengembangan ilmu pemasaran khususnya di Indonesia, dapat memberikan wawasan yang lebih luas mengenai kualitas pelayanan pada kedua BPR dan dapat menjadi referensi untuk penelitian selanjutnya. Kegunaan praktis berupa menjadi pedoman bagi manajemen bank baik dari PT BPR. Mertha Sedana dan PT. BPR. Mas Giri Wangi untuk meningkatkan kualitas pelayanan sehingga dapat menunjang kinerja perusahaan dan meningkatkan laba perusahaan.

Kualitas pelayanan merupakan suatu bentuk penilaian terhadap tingkat pelayanan yang diberikan oleh bank apakah pelayanannya memuaskan atau tidak memuaskan. Buruknya kualitas pelayanan pada bank akan memberikan dampak negatif pada kinerjanya. Berdasarkan penelitian yang dilakukan oleh Waguespack et al. (2007) dan Tidtichumremporn et al. (2010) menyatakan bahwa kualitas pelayanan dari sebuah jasa tidak dapat dikesampingkan, karena dapat meningkatkan keunggulan kompetitif dalam memperoleh nasabah dan kepuasan dari nasabah. Perusahaan diharapkan mampu untuk memberikan kualitas pelayanan yang prima sehingga akan berdampak pada kepuasan nasabah dan juga profitabilitas bank. Kualitas pelayanan telah dikonseptualisasikan sebagai perbedaan antara harapan pelanggan mengenai pelayanan yang akan diterima dan persepsi jasa yang diterima (Parasuraman et al. dalam Akbar dan Parves, 2009). Kualitas pelayanan merupakan sebuah konsep multidimensi. Dimensi kualitas pelayanan dapat diidentifikasi melalui penelitian yang dilakukan oleh Parasuraman et al. yang dikenal sebagai SERVQUAL (Services Quality) (Kotler dan Keller, 2007:56). SERVQUAL telah terbukti menjadi model yang telah 
banyak digunakan dalam berbagai organisasi dan industri untuk mengukur kualitas pelayanan termasuk bank (Siddiqi, 2011 dan Lymperopoulos et al. 2006).

Dimensi pertama "tangible", yang terkait dengan fasilitas fisik peralatan dan personil. Dimensi kedua "reliability", berkaitan dengan kemampuan untuk melakukan layanan prima yang diinginkan, akurat dan konsisten. Dimensi ketiga "responsiveness", terkait dengan kesediaan untuk memberikan layanan dan bantuan pelanggan. Dimensi keempat "assurance", berkaitan dengan pengetahuan, kesopanan, dan kemampuan untuk memberikan kepercayaan dan keyakinan. Dimensi terakhir yakni "empaty", yang dimaksud sebagai kepedulian dan memberikan perhatiaan individual kepada pelanggan.

Sebelumnya ada beberapa penelitian yang telah dilakukan mengenai studi komparatif pada kualitas pelayanan perbankan. Berdasarkan studi yang dilakukan oleh Haque (2011) penelitian untuk mengukur dan membandingkan tingkat kualitas pelayanan yang diberikan perbankan ritel di India pada sektor bank swasta dan bank umum dimana hasil pada penelitian tersebut dijelaskan bahwa kualitas pelayanan pada sektor bank umum harus tetap ditingkatkan. Sedangkan pada penelitian lain yang dilakukan oleh Nalim (2015) tujuan dari penelitiannya adalah penelitian ini mencoba mengungkap faktor-faktor yang mempengaruhi nasabah memilih bank (syariah atau konvensional), mengetahui indeks layanan bank syariah dan konvensional, serta mengetahui perbedaan kualitas layanan antara bank syariah dan konvensional. Dari hasil penelitiannya adalah dimensi kualitas pelayanan yang paling baik di bank syariah dan konvensional adalah dimensi tangible dengan skor berturut-turut sebesar 3,69 dan 3,65. Terdapat 
perbedaan indeks kualitas pelayanan antara bank syariah dan bank konvensional di Kota Pekalongan.

Kepuasan konsumen (nasabah) merupakan suatu ungkapan seseorang dalam memberikan nilai, atau mengoptimalkan nilai yang dirasakan dan diharapkan seseorang terhadap suatu produk atau jasa (Sunarto, 2006). Kepuasan dapat dirasakan oleh sesorang melalui perasaan senang atau kecewa yang muncul setelah membandingkan antara kesan akan kinerja yang diterima atau didapatkan melalui sebuah pelayanan. Menurut Tse dan Wilton dalam Tjiptono (2006:146) kepuasan atau ketidakpuasaan pelanggan adalah respon pelanggan terhadap evaluasi ketidaksesuaian yang dirasakan antara harapan sebelumnya (norma kinerja lainnya) dan kinerja aktual produk yang dirasakan setelah pemakaiannya. Kepuasan pelanggan merupakan suatu hal yang sangat penting yang diharapkan oleh semua usaha agar mampu memberikan kepuasan terhadap para pelanggannya. Menurut Mohammad (2004) kepuasan pelanggan merupakan salah satu kunci keberhasilan suatu usaha. Hal ini dikarenakan dengan memuaskan konsumen, organisasi atau suatu usaha dapat meningkatkan tingkat keuntungannya dan juga dapat memperluas pangsa pasar yang dimilikinya.

Penelitian sebelumnya telah membuktikan bahwa banyak faktor yang mempengaruhi kepuasan nasabah salah satunya adalah kualitas pelayanan. Aypar et al. (2010) menyatakan bahwa kualitas pelayanan merupakan faktor yang mampu mempengaruhi secara positif kepuasan nasabah. Gunadi (2002) mengatakan bahwa kualitas layanan yang terdiri dari bukti fisik, keandalan dan daya tanggap karyawan berpengaruh signifikan dan mampu mempertahankan 
kepuasan nasabah. Dalam penelitian Anggabrata (2014) juga menyimpulkan bahwa kualitas pelayanan berpengaruh secara signifikan positif terhadap kepuasan nasabah PT. BPR Balidana Niaga Denpasar. Berdasarkan landasan teori dan penelitian sebelumnya maka dapat dirumuskan hipotesis sebagai berikut:

1) Kualitas pelayanan (bukti fisik, keandalan, daya tanggap, jaminan dan empati) berpengaruh positif dan signifikan terhadap kepuasan nasabah PT. BPR. Mertha Sedana.

2) Kualitas pelayanan (bukti fisik, keandalan, daya tanggap, jaminan dan empati) berpengaruh positif dan signifikan terhadap kepuasan nasabah PT. BPR. Mas Giri Wangi.

\section{METODE PENELITIAN}

Penelitian ini merupakan jenis penelitian komparatif asosiatif. Penelitian ini bertujuan untuk mengetahui pengaruh kualitas pelayanan terhadap kepuasan nasabah dengan membandingkan variabel tersebut pada 2 BPR, yaitu PT. BPR Mertha Sedana dan PT. BPR Mas Giri Wangi.Penelitian ini dilakukan di dua lokasi yang berbeda, yaitu Kabupaten Badung dan Kabupaten Giayar, hal ini terjadi karena PT. BPR Mertha Sedana yang berlokasi di kabupaten Badung sedangkan PT. BPR Mas Giri Wangi yang berlokasi di kabupaten Gianyar.Objek penelitian ini adalah kepuasan nasabah PT. BPR. Mertha Sedana dan PT. BPR. Mas Giri Wangi yang dipengaruhi oleh kualitas pelayanan.

Penelitian ini melibatkan 2 jenis variabel, yaitu variabel bebas dan variabel terikat. Variabe bebas yang digunakan berupa kualitas pelayanan (X), kualitas 
Kadek Ari Dwi Divayana, Studi Komparatif Pengaruh...

pelanan ini memiliki 5 dimensi, diantaranya : Bukti fisik, Keandalan, Daya tanggap, Jaminan dan Empati. Variabel terikat dalam penelitian ini adalah Kepuasan Nasabah (Y). Indikator yang digunakan untuk mengukur kedua variabel ini disajikan dalam Tabel 3 sebagai berikut,

Tabel 3.

Tabel Indikator Penelitian

\begin{tabular}{|c|c|c|c|}
\hline No & Variabel & Indikator & Sumber \\
\hline \multirow[t]{5}{*}{1.} & Tangible & 1. Lokasi kantor & Siddiqi (2011) \\
\hline & & 2. Fasilitas kantor yang modern & Parasuraman et al. (1988), \\
\hline & & 3. Penampilan karyawan & Siddiqi (2011) dan \\
\hline & & 4. Kebersihan kantor & Choudhury (2008) \\
\hline & & 5. Eksterior kantor & Al- Rousan et al. (2010) \\
\hline \multirow[t]{5}{*}{2.} & Reliability & 1. Memberikan layanan seperti & Siddiqi (2011) dan \\
\hline & & yang dijanjikan & Choudhury (2008) \\
\hline & & 2. Ketepatan waktu pelayanan & Parasuraman et al. (1988) \\
\hline & & 3. Verifikasi permintaan & Choundhury (2008) \\
\hline & & 4. Ketulusan membantu & Mishra et al.(2010) \\
\hline \multirow[t]{4}{*}{3.} & Responsiveness & 1. Kesediaan staf membantu & Choudhury (2008) dan \\
\hline & & 2. Pemberitahuan waktu pelayanan & Parasuraman et al. (1988) \\
\hline & & 3. Kecepatan pelayanan & Choudhury (2008) \\
\hline & & 4. Kesiapan melayani & \\
\hline \multirow[t]{5}{*}{4.} & Assurance & $\begin{array}{l}\text { 1. Keyakinan terhadap kemampuan } \\
\text { karyawan }\end{array}$ & $\begin{array}{l}\text { Parasuraman et al. (1988) } \\
\text { dan Mishra et al. }(2010)\end{array}$ \\
\hline & & 2. Kesopanan karyawan terhadap & Parasuraman et al. (1988) \\
\hline & & nasabah & Choudhury (2008) \\
\hline & & 3. Rasa aman bertransaksi & \\
\hline & & $\begin{array}{l}\text { 4. Karyawan menanamkan } \\
\text { kepercayaan pada nasabah }\end{array}$ & \\
\hline \multirow[t]{4}{*}{5.} & Emphaty & 1. Menyapa nasabah dengan nama & Al-Rousan et al. (2010) \\
\hline & & $\begin{array}{l}\text { 2. Permintaan maaf kesalahan } \\
\text { service }\end{array}$ & $\begin{array}{l}\text { Choudhury (2008), Mishra } \\
\text { et al., (2010) dan }\end{array}$ \\
\hline & & $\begin{array}{l}\text { 3. Memahami kebutuhan } \\
\text { nasabahnya }\end{array}$ & Parasuraman et al. (1988) \\
\hline & & $\begin{array}{l}\text { 4. Perhatian secara personal } \\
\text { 5. Waktu operasional }\end{array}$ & \\
\hline \multirow[t]{4}{*}{6.} & Costumer & 1. Kepuasan pelayanan & Presbury et al.(2005) \\
\hline & Satisfaction & 2. Kepuasan pada produk & Melissa (2010) \\
\hline & (Kepuasan) & yangditawarkan & Kuestanto (2014) \\
\hline & & 3. Memberikan rekomendasi & \\
\hline
\end{tabular}

Jenis data yang digunakan dalam penelitan ini adalah jenis data yang dikelompokkan menurut sifatnya, yaitu data kualitatif dan data kuantitatif.Data kualitatif dalam penelitian ini berupa pendapat dari responden mengenai pernyataan yang tertera di dalam kuisioner dan sejarah singkat perusahaan.Data 
kuantitatif dalam penelitian ini adalah data yang berupa angka-angka yang dapat dihitung seperti hasil jawaban dari skor kuesioner dan jumlah responden. Sumber data yang digunakan dalam penelitian ini adalah sumber data primer dan sekunder.Sumber primer dalam penelitian ini berasal dari responden yang memberikan tanggapan dalam kuesioner mengenai variabel - variabel dalam penelitian.Sumber sekunder dalam penelitian ini berasal dari institusi atau pihak lain yang telah mempublikasikan data yang dikutip terkait dengan topik penelitian ini.

Populasi dalam penelitian ini adalah para nasabah dari PT. BPR. Mertha Sedana dan PT. BPR. Mas Giri Wangi. Jumlah sampel yang digunakan adalah 510 kali jumlah parameter yang diestimasi (Ferdinand, 2002). Dalam penelitian ini menggunakan 25 indikator sehingga banyaknya responden yang diambil sebagai sempel adalah $5 \times 25=125$ orang. Penelitian ini menggunakan $2 \mathrm{BPR}$ maka jumlah sampel tersebut akan dibagi menjadi 2. Jumlah sampel yang akan diambil untuk masing-masing BPR adalah 65 orang. Adapun teknik pengambilan sampel yang digunakan dalam penelitian ini adalah Purposive Sampling, sehingga dalam menentukan sampel, diperlukan kriteria tertentu, adapun kriteria yang digunakan adalah pendidikan terakhir minimal SMA/SMK sederajat, Nasabah bank dan Pernah melakukan Transaksi pada BPR terkait.

Metode pengumpulan data pada penelitian ini menggunakan 3 metode, yaitu metode wawancara, dokumentasi dan kuesioner. Pada metode kuesioner, responden diberikan pertanyaan seputar variabel kualitas pelayanan dan kepuasan nasabah.Penyebaran kuisoner dilakukan secara langsung oleh peneliti.Kuesioner 
terdiri dari pertanyaan terbuka yaitu identitas diri responden dan pernyataan yang berkaitan dengan indikator - indikator penelitian. Pernyataan dalam kuisioner akan diukur dengan menggunakan skala likert dengan skala 1 sampai dengan 5 dengan keterangan seperti dalam Tabel 4 sebagai berikut,

Tabel 4.

Tabel Alternatif Jawaban Responden

\begin{tabular}{ccc}
\hline Simbol & Alternatif Jawaban & Skor \\
\hline SS & Sangat setuju & 5 \\
S & Setuju & 4 \\
N & Netral & 3 \\
TS & Tidak Setuju & 2 \\
STS & Sangat Tidak Setuju & 1 \\
\hline \multicolumn{2}{l}{ Sumber $:$ Sugiyono, 2014 }
\end{tabular}

Instrumen penelitian berupa kuesioner, diuji validitas dan reliabilitasnya terlebih dahulu. Uji validitas bertujuan untuk memeriksa apakah kuesioner sebagai instrument penelitian sudah tepat untuk mengukur indikator dalam penelitian. Kuesioner dapat dikatakan valid apabila koefisien korelasi $\geq 0,3$ (Sugiyono, 2014).Uji Reliabilitas dapat digunakan untuk menunjukan sejauh mana alat pengukur yang digunakan dapat dipercaya. Instrumen dapat dikatarkan valid jika Alpha Cronbach $\geq 0,6$.Teknik analisi yang digunakan adalah regresi linier berganda. Teknik ini digunakan untuk mengetahui ketergantungan suatu variabel terikat dengan satu atau lebih variabel bebas. Sebelum menggunakan teknik analisis linier berganda, terlebih dahulu dilakukan Uji Asumsi Klasik yang meliputi uji multikolinieritas, uji heteroskedastisitas dan Uji Normalitas.

\section{HASIL DAN PEMBAHASAN}

Dalam mengetahui gambaran umum responden yang terlibat, dapat diketahui dengan melihat karakteristik responden. Karakteristik responden 
digolongkan kedalam variabel demografi yang terdiri dari jenis kelamin, umur, dan jenjang pendidikan terakhir. Adapun rincian mengenai karakteristik pada masing - masing nasabah kedua BPR yang terlibat disajikan pada Tabel 5 sebagai berikut.

Tabel 5.

Karakteristik Responden

\begin{tabular}{|c|c|c|c|c|c|c|}
\hline \multirow[t]{2}{*}{ No. } & \multirow[t]{2}{*}{ Variabel } & \multirow[t]{2}{*}{ Klasifikasi } & \multicolumn{2}{|c|}{$\begin{array}{l}\text { PT. BPR Mertha } \\
\text { Sedana } \\
\end{array}$} & \multicolumn{2}{|c|}{$\begin{array}{c}\text { PT. BPR Mas Giri } \\
\text { Wangi } \\
\end{array}$} \\
\hline & & & Jumlah & Persentase & Jumlah & Persentase \\
\hline \multirow[t]{3}{*}{1.} & Jenis Kelamin & Laki-laki & 30 & 46,15 & 27 & 41,54 \\
\hline & & Perempuan & 35 & 53,85 & 38 & 58,46 \\
\hline & & Jumlah & 65 & 100,0 & 65 & 100,0 \\
\hline \multirow[t]{5}{*}{2.} & Umur & $17-25$ tahun & 10 & 15,38 & 10 & 15,38 \\
\hline & & $26-35$ tahun & 24 & 36,93 & 25 & 38,46 \\
\hline & & $36-45$ tahun & 16 & 24,61 & 18 & 27,70 \\
\hline & & $46-60$ tahun & 15 & 23,08 & 12 & 17,46 \\
\hline & & Jumlah & 65 & 100,0 & 65 & 100,0 \\
\hline \multirow[t]{3}{*}{3.} & Pendidikan terakhir & SMA & 34 & 52,30 & 38 & 58,47 \\
\hline & & Perguruan tinggi & 31 & 47,70 & 27 & 41,54 \\
\hline & & Jumlah & 65 & 100,0 & 65 & 100,0 \\
\hline
\end{tabular}

Sumber : Data diolah, 2017

Data pada Tabel 5. diketahui responden dari nasabah PT. BPR Mertha Sedana didominasi oleh $53,85 \%$ perempuan. Dari sisi umur, sebesar $36,93 \%$ didominasi oleh responden dengan pada kisaran umur 26 - 35 tahun. Sebesar 47,7\% responden didominasi dengan jenjang pendidikan minimal perguruan tinggi. Nasabat PT. BPR Giri Wangi yang menjadi responden didominasi sebesar $58,46 \%$ oleh perempuan. Sebesar 38,46\% responden didominasi oleh rentang usia 26 - 35 tahun, dan sebesar $41,45 \%$ responden berjenjang pendidikan minimal perguruan tinggi.

Suatu instrumen dalam penelitian dikatakan valid apabila lolos uji validitas dan reliabilitas. Hasil uji validitas dan reliabilitas pada masing - masing variabel dapat dilihat pada Tabel 6. sebagai berikut : 
Tabel 6.

Hasil Uj Validitas dan Reliabilitas

\begin{tabular}{|c|c|c|c|c|c|}
\hline No. & Variabel & Indikator & $\begin{array}{c}\text { Uji Validitas } \\
\text { Koef Korelasi }\end{array}$ & $\begin{array}{c}\text { Uji Reliabilitas } \\
\text { Alnha Cronhach }\end{array}$ & Ket \\
\hline \multirow[t]{5}{*}{1.} & Bukti Fisik $\left(\mathrm{X}_{1}\right)$ & $\mathrm{X} 1.1$ & 0,863 & \multirow{5}{*}{0,883} & \multirow{5}{*}{ Valid } \\
\hline & & $\mathrm{X} 1.2$ & 0,801 & & \\
\hline & & $\mathrm{X} 1.3$ & 0,827 & & \\
\hline & & X1.4 & 0,826 & & \\
\hline & & $\mathrm{X} 1.5$ & 0,824 & & \\
\hline \multirow[t]{4}{*}{2.} & Kendalan $\left(\mathrm{X}_{2}\right)$ & $\mathrm{X} 2.1$ & 0,936 & \multirow{4}{*}{0,914} & \multirow{4}{*}{ Valid } \\
\hline & & $\mathrm{X} 2.2$ & 0,912 & & \\
\hline & & $\mathrm{X} 2.3$ & 0,862 & & \\
\hline & & $\mathrm{X} 2.4$ & 0,863 & & \\
\hline \multirow[t]{4}{*}{3.} & Daya Tanggap $\left(\mathrm{X}_{3}\right)$ & X3.1 & 0,891 & \multirow{4}{*}{0,914} & \multirow{4}{*}{ Valid } \\
\hline & & $\mathrm{X} 3.2$ & 0,882 & & \\
\hline & & X3.3 & 0,905 & & \\
\hline & & $\mathrm{X} 3.4$ & 0,888 & & \\
\hline \multirow[t]{4}{*}{4.} & Jaminan $\left(X_{4}\right)$ & $\mathrm{X} 4.1$ & 0,911 & \multirow{4}{*}{0,926} & \multirow{4}{*}{ Valid } \\
\hline & & $\mathrm{X} 4.2$ & 0,933 & & \\
\hline & & $\mathrm{X} 4.3$ & 0,917 & & \\
\hline & & $\mathrm{X} 4.4$ & 0,861 & & \\
\hline \multirow[t]{5}{*}{5.} & Empaty $\left(\mathrm{X}_{5}\right)$ & $\mathrm{X} 5.1$ & 0,841 & \multirow{5}{*}{0,928} & \multirow{5}{*}{ Valid } \\
\hline & & $\mathrm{X} 5.2$ & 0,882 & & \\
\hline & & $\mathrm{X} 5.3$ & 0,914 & & \\
\hline & & $\mathrm{X} 5.4$ & 0,904 & & \\
\hline & & $\mathrm{X} 5.5$ & 0,868 & & \\
\hline \multirow[t]{3}{*}{6.} & Kepuasan Nasabah (Y) & Y1.1 & 0,929 & \multirow{3}{*}{0,914} & \multirow{3}{*}{ Valid } \\
\hline & & Y1.2 & 0,915 & & \\
\hline & & Y1.3 & 0,929 & & \\
\hline
\end{tabular}

Sumber: Data diolah, 2017

Data pada Tabel 6. menunjukkan bahwa masing-masing indikator variabel merupakan indicator yang valid dan reliable untuk digunakan. Rata - rata skor jawaban responden pada kuesioner dikelompokkan kedalam 5 kelas interval rentang penilaian seperti pada Tabel 7. sebagai berikut

Tabel 7.

\begin{tabular}{ccc}
\multicolumn{3}{c}{ Rentang Penilaian Jawaban Responden } \\
\hline No. & Rentang Skor & Keterangan \\
\hline 1. & $1,00-1,80$ & Sangat tidak baik \\
2. & $1,81-2,60$ & Tidak baik \\
3. & $2,61-3,40$ & Cukup baik \\
4. & $3,41-4,20$ & Baik \\
5. & $4,21-5,00$ & Sangat baik \\
\hline Sumber : & Suharsono, 2010 &
\end{tabular}

Deskripsi jawaban responden mengenai kualitas pelayanan dan kepuasan nasabah PT. BPR Mertha Sedana disajikan dalam Tabel 8. sebagai berikut. 
Tabel 8.

Deskripsi Jawaban Responden PT. BPR Mertha Sedana

\begin{tabular}{|c|c|c|c|c|c|c|c|c|}
\hline \multirow{2}{*}{ Variabel } & \multirow{2}{*}{ Indikator } & \multicolumn{5}{|c|}{ Skor Jawaban } & \multirow{2}{*}{$\begin{array}{l}\text { Jum. } \\
\text { Skor }\end{array}$} & \multirow{2}{*}{$\begin{array}{l}\text { Rata } \\
\text {-Rata }\end{array}$} \\
\hline & & 1 & 2 & 3 & 4 & 5 & & \\
\hline \multirow[t]{6}{*}{ Bukti fisik } & Lokasi kantor & 0 & 1 & 14 & 26 & 24 & 268 & 4,12 \\
\hline & Fasilitas kantor Modern & 0 & 1 & 22 & 28 & 14 & 250 & 3,85 \\
\hline & Penampilan karyawan & 0 & 1 & 18 & 29 & 17 & 257 & 3,95 \\
\hline & Ruang tunggu & 0 & 2 & 20 & 23 & 20 & 256 & 3,94 \\
\hline & Tempat parkir memadai & 0 & 2 & 18 & 22 & 23 & 261 & 4,02 \\
\hline & Rata - rata total & & & & & & & 3,98 \\
\hline \multirow[t]{4}{*}{ Keandalan } & Memberikan Layanan yang baik & 0 & 0 & 11 & 24 & 30 & 279 & 4,29 \\
\hline & Memberikan layanan yang cepat & 0 & 1 & 11 & 29 & 24 & 271 & 4,17 \\
\hline & $\begin{array}{l}\text { Memberikan layanan yang tepat sesuai } \\
\text { dengan kebutuhan }\end{array}$ & 0 & 0 & 17 & 27 & 21 & 264 & 4,06 \\
\hline & $\begin{array}{l}\text { Memberikan solusi yang tepat } \\
\text { Rata - rata total }\end{array}$ & 0 & 1 & 22 & 27 & 15 & 251 & $\begin{array}{l}3,86 \\
\mathbf{4 , 1 0}\end{array}$ \\
\hline \multirow{5}{*}{$\begin{array}{l}\text { Daya } \\
\text { tanggap }\end{array}$} & Merespon keluhan dengan baik & 0 & 0 & 20 & 26 & 19 & 259 & 3,98 \\
\hline & Pemberitahuan waktu pelayanan & 0 & 0 & 19 & 26 & 20 & 261 & 4,02 \\
\hline & Cepat tanggap dalam menangani masalah & 0 & 0 & 14 & 29 & 22 & 268 & 4,12 \\
\hline & Dapat menyelesaikan permasalahan & 0 & 0 & 27 & 22 & 16 & 249 & 3,83 \\
\hline & Rata - rata total & & & & & & & 3,99 \\
\hline \multirow[t]{5}{*}{ Jaminan } & $\begin{array}{l}\text { Karyawan memiliki kemampuan yang } \\
\text { baik dalam melayani nasabah }\end{array}$ & 0 & 1 & 19 & 26 & 19 & 258 & 3,97 \\
\hline & Kesopanan karyawan terhadap nasabah & 0 & 0 & 19 & 25 & 21 & 262 & 4,03 \\
\hline & Rasa aman bertransaksi & 0 & 0 & 21 & 16 & 28 & 267 & 4,11 \\
\hline & $\begin{array}{l}\text { Karyawan menamakan kepercayaan } \\
\text { kepada nasabah }\end{array}$ & 0 & 1 & 24 & 20 & 10 & 254 & 3,91 \\
\hline & Rata - rata total & & & & & & & 4,00 \\
\hline \multirow[t]{6}{*}{ Empati } & $\begin{array}{l}\text { Menyapa nasabah dengan identitas yang } \\
\text { benar }\end{array}$ & 0 & 0 & 16 & 27 & 22 & 266 & 4,09 \\
\hline & $\begin{array}{l}\text { Permintaan maaf ketika kesalahan } \\
\text { service }\end{array}$ & 0 & 1 & 19 & 22 & 23 & 262 & 4,03 \\
\hline & Mengutamakan kepentingan nasabah & 0 & 0 & 19 & 22 & 24 & 265 & 4,08 \\
\hline & Perhatian secara personal & 0 & 0 & 19 & 25 & 21 & 262 & 4,03 \\
\hline & Waktu operasional & 0 & 1 & 18 & 25 & 21 & 261 & 4,02 \\
\hline & Rata - rata total & & & & & & & 4,05 \\
\hline \multirow{4}{*}{$\begin{array}{l}\text { Kepuasan } \\
\text { Nasabah }\end{array}$} & Kepuasan pelayanan & 0 & 0 & 22 & 17 & 26 & 264 & 4,06 \\
\hline & $\begin{array}{l}\text { Kepuasan kepada produk keuangan } \\
\text { yang ditawarkan }\end{array}$ & 0 & 2 & 19 & 18 & 26 & 263 & 4,05 \\
\hline & $\begin{array}{l}\text { Nasabah merekomendasikan pada orang } \\
\text { lain }\end{array}$ & 0 & 1 & 22 & 17 & 25 & 261 & 4,02 \\
\hline & Rata - rata total & & & & & & & 4,04 \\
\hline
\end{tabular}

Sumber : Data diolah, 2017

Berdasarkan data pada Tabel 8, diketahui total rata-rata skor untuk variabel

Bukti fisik, keandalan, daya tanggap, jaminan, empati, dan kepuasan nasabah masuk dalam kategori baik. Secara umum, nasabah PT. BPR Mertha Sedana, menilai pelayanan yang diberikan baik, sehingga kepuasan yang tercipta juga baik. 
Tabel 9.

Deskripsi Jawaban Responden PT. BPR Mas Giri Wangi

\begin{tabular}{|c|c|c|c|c|c|c|c|c|}
\hline \multirow{2}{*}{ Variabel } & \multirow{2}{*}{ Indikator } & \multicolumn{5}{|c|}{ Skor Jawaban } & \multirow{2}{*}{$\begin{array}{l}\text { Jum. } \\
\text { Skor }\end{array}$} & \multirow{2}{*}{$\begin{array}{l}\text { Rata } \\
\text {-Rata }\end{array}$} \\
\hline & & 1 & 2 & 3 & 4 & 5 & & \\
\hline \multirow[t]{6}{*}{ Bukti fisik } & Lokasi kantor & 0 & 0 & 15 & 24 & 26 & 271 & 4,17 \\
\hline & Fasilitas kantor Modern & 0 & 0 & 24 & 27 & 14 & 250 & 3,85 \\
\hline & Penampilan karyawan & 0 & 0 & 19 & 24 & 22 & 263 & 4,05 \\
\hline & Ruang tunggu & 0 & 0 & 18 & 23 & 24 & 266 & 4,09 \\
\hline & Tempat parkir memadai & 0 & 1 & 16 & 23 & 25 & 267 & 4,11 \\
\hline & Rata - rata total & & & & & & & 4,05 \\
\hline \multirow{5}{*}{ Keandalan } & Memberikan Layanan yang baik & 0 & 0 & 9 & 32 & 24 & 275 & 4,23 \\
\hline & Memberikan layanan yang cepat & 0 & 0 & 13 & 30 & 22 & 269 & 4,14 \\
\hline & $\begin{array}{l}\text { Memberikan layanan yang tepat sesuai } \\
\text { dengan kebutuhan }\end{array}$ & 0 & 0 & 14 & 27 & 24 & 270 & 4,15 \\
\hline & Memberikan solusi yang tepat & 0 & 0 & 27 & 25 & 23 & 266 & 4,09 \\
\hline & Rata - rata total & & & & & & & 4,15 \\
\hline Daya & Merespon keluhan dengan baik & 0 & 0 & 18 & 24 & 23 & 265 & 4,08 \\
\hline \multirow[t]{4}{*}{ tanggap } & Pemberitahuan waktu pelayanan & 0 & 0 & 17 & 25 & 23 & 266 & 4,09 \\
\hline & $\begin{array}{l}\text { Cepat tanggap dalam menangani } \\
\text { permasalahan }\end{array}$ & 0 & 0 & 17 & 26 & 22 & 265 & 4,08 \\
\hline & $\begin{array}{l}\text { Selalu dapat menyelesaikan } \\
\text { permasalahan }\end{array}$ & 0 & 0 & 21 & 25 & 19 & 258 & 3,97 \\
\hline & Rata - rata total & & & & & & & 4,05 \\
\hline \multirow[t]{5}{*}{ Jaminan } & $\begin{array}{l}\text { Karyawan memiliki kemampuan yang } \\
\text { baik dalam melayani nasabah }\end{array}$ & 0 & 0 & 8 & 33 & 24 & 276 & 4,25 \\
\hline & Kesopanan karyawan terhadap nasabah & 0 & 0 & 17 & 28 & 20 & 263 & 4,05 \\
\hline & Rasa aman bertransaksi & 0 & 0 & 15 & 26 & 24 & 269 & 4,14 \\
\hline & $\begin{array}{l}\text { Karyawan menamakan kepercayaan } \\
\text { kepada nasabah }\end{array}$ & 0 & 1 & 18 & 27 & 19 & 259 & 3,98 \\
\hline & Rata - rata total & & & & & & & 4,10 \\
\hline \multirow[t]{6}{*}{ Empati } & $\begin{array}{l}\text { Menyapa nasabah dengan identitas } \\
\text { yang benar }\end{array}$ & 0 & 0 & 9 & 25 & 31 & 282 & 4,34 \\
\hline & $\begin{array}{l}\text { Permintaan maaf ketika kesalahan } \\
\text { service }\end{array}$ & 0 & 0 & 20 & 20 & 25 & 265 & 4,08 \\
\hline & Mengutamakan kepentingan nasabah & 0 & 0 & 16 & 20 & 29 & 273 & 4,20 \\
\hline & Perhatian secara personal & 0 & 0 & 17 & 22 & 26 & 269 & 4,14 \\
\hline & Waktu operasional & 0 & 0 & 16 & 24 & 25 & 269 & 4,14 \\
\hline & Rata - rata total & & & & & & & 4,18 \\
\hline \multirow{4}{*}{$\begin{array}{l}\text { Kepuasan } \\
\text { Nasabah }\end{array}$} & Kepuasan pelayanan & 0 & 0 & 24 & 13 & 28 & 264 & 4,06 \\
\hline & $\begin{array}{l}\text { Kepuasan kepada produk keuangan } \\
\text { yang ditawarkan }\end{array}$ & 0 & 1 & 22 & 18 & 24 & 260 & 4,00 \\
\hline & $\begin{array}{l}\text { Nasabah merekomendasikan pada } \\
\text { orang lain }\end{array}$ & 0 & 0 & 25 & 11 & 29 & 264 & 4,06 \\
\hline & Rata - rata total & & & & & & & 4,04 \\
\hline
\end{tabular}

Sumber: data diolah, 2017

Variabel Bukti fisik memiliki skor 4,05 yang masuk dalam kategori baik terhadap item pertanyaan pada variabel Bukti fisik. Indikator pertama merupakan indikator yang mempunyai nilai skor rata-rata tertinggi yakni lokasi kantor. Variabel keandalan memiliki skor rata - rata 4,15 yang berada pada kategori 
baik.berarti bahwa secara keseluruhan responden memberikan respon baik terhadap item pertanyaan pada variabel Keandalan. Variabel daya tanggap memiliki skor rata - rata 4,05 yang masuk dalam kategori baik. Pada variabel jaminan, skor rata - ratanya adalah 4,10 yang masuk dalam kategori baik. Variabel empati memiliki skor rata - rata jawaban 4,18 masuk dalam kategori baik. Variabel Kepuasan nasabah memiliki skor rata - rata jawaban 4,04 yang masuk dalam kategori baik.Secara umum, nasabah PT. BPR Mas Giri Wangi, menilai pelayanan yang diberikan bank baik, sehingga kepuasan yang tercipta juga baik.

Hasil analisis regresi linier berganda pada PT. BPR Mertha Sedana yang diperoleh dari hasil pengolahan data melalui program SPSS disajikan pada Tabel 10 sebagai berikut,

Tabel 10.

Hasil Analisis Regresi Linier Berganda PT. BPR. Mertha Sedana

\begin{tabular}{|c|c|c|c|c|}
\hline \multirow{2}{*}{ Variabel } & \multicolumn{2}{|c|}{ Koefisien Regresi } & \multirow{2}{*}{$\mathrm{t}$} & \multirow[b]{2}{*}{ Sig } \\
\hline & $\mathrm{B}$ & Std. error & & \\
\hline (constant) & $-2,457$ & 0,601 & $-4,087$ & 0,000 \\
\hline Bukti Fisik & 0,102 & 0,050 & 2,031 & 0,047 \\
\hline Keandalan & 0,164 & 0,080 & 2,061 & 0,044 \\
\hline Daya Tanggap & 0,194 & 0,077 & 2,518 & 0,015 \\
\hline Jaminan & 0,198 & 0,074 & 2,674 & 0,010 \\
\hline Empati & 0,177 & 0,070 & 2,544 & 0,014 \\
\hline Dependen Variabel & \multicolumn{4}{|c|}{ : Customer Satisfaction } \\
\hline F Statistik & \multicolumn{4}{|c|}{$: 125,486$} \\
\hline Sig F & \multicolumn{4}{|l|}{$: 0,000$} \\
\hline $\mathrm{R}$ square & \multicolumn{4}{|l|}{$: 0,914$} \\
\hline Adjusted $\mathrm{R}^{2}$ & \multicolumn{4}{|l|}{ : 0,907} \\
\hline
\end{tabular}

Dari data pada Tabel 10, maka persamaan regresi linier berganda sebagai berikut: $Y=-2,457+0,102 X_{1}+0,164 X_{2}+0,194 X_{3}+0,198 X_{4}+0,177 X_{5}$ 
Berdasrkan persamaan diatas dapat dijelaskan bahwa persamaan regresi diatas menunjukkan adanya pengaruh positif (searah) dimana peningkatan pada kualitas pelayanan akan berdampak pada meningkatnya kepuasan nasabah di PT. BPR. Mertha Sedana.

Hasil analisis regresi linier berganda pada PT. BPR Mas Giri Wangidisajikan pada Tabel 11 sebagai berikut,

Tabel 11.

Hasil Analisis Regresi Linier Berganda PT. BPR. Mas Giri Wangi

\begin{tabular}{|c|c|c|c|c|}
\hline \multirow{2}{*}{ Variabel } & \multicolumn{2}{|c|}{ Koefisien Regresi } & \multirow{2}{*}{$\mathrm{t}$} & \multirow{2}{*}{ Sig } \\
\hline & $\mathrm{B}$ & Std. error & & \\
\hline (constant) & $-4,009$ & 0,999 & $-4,012$ & 0,000 \\
\hline Bukti Fisik & 0,159 & 0,073 & 2,161 & 0,035 \\
\hline Keandalan & 0,230 & 0,101 & 2,287 & 0,026 \\
\hline Daya Tanggap & 0,191 & 0,091 & 2,108 & 0,039 \\
\hline Jaminan & 0,169 & 0,079 & 2,128 & 0,038 \\
\hline Empati & 0,154 & 0,070 & 2,197 & 0,032 \\
\hline Dependen Variabel & \multicolumn{4}{|c|}{ : Customer Satisfaction } \\
\hline F Statistik & \multicolumn{4}{|l|}{ : 54,928} \\
\hline Sig F & \multicolumn{4}{|l|}{$: 0,000$} \\
\hline $\mathrm{R}$ square & \multicolumn{4}{|l|}{$: 0,823$} \\
\hline Adjusted $\mathrm{R}^{2}$ & \multicolumn{4}{|l|}{0,808} \\
\hline
\end{tabular}

Dari data pada Tabel 11, maka persamaan regresi linier berganda sebagai berikut: $Y=-4,009+0,159 X_{1}+0,230 X_{2}+0,191 X_{3}+0,169 X_{4}+0,154 X_{5}$

Berdasrkan persamaan diatas dapat dijelaskan bahwa persamaan regresi diatas menunjukkan adanya pengaruh positif (searah) dimana peningkatan pada kualitas pelayanan akan berdampak pada meningkatnya kepuasan nasabah di PT. BPR. Mas Giri Wangi.

Hasil uji multikolinearitas PT. BPR Mertha Sedana dan PT. BPR Mas Giri Wangi disajikan pada Table 12 sebagai berikut. 
Tabel 12.

Hasil Uji Multikolinearitas

\begin{tabular}{|c|c|c|c|c|}
\hline \multirow{3}{*}{ Variabel Bebas } & \multicolumn{2}{|c|}{ PT. BPR Mertha Sedana } & \multicolumn{2}{|c|}{ PT. BPR Mas Giri Wangi } \\
\hline & \multicolumn{4}{|c|}{ Colinearity Statistic } \\
\hline & Tolerance & VIF & Tolerance & VIF \\
\hline Bukti Fisik & 0,293 & 3,416 & 0,337 & 2,971 \\
\hline Keandalan & 0,184 & 5,447 & 0,297 & 3,372 \\
\hline Daya Tanggap & 0,199 & 5,017 & 0,317 & 3,151 \\
\hline Jaminan & 0,183 & 5,447 & 0,430 & 2,325 \\
\hline Empati & 0,149 & 6,721 & 0,314 & 3,188 \\
\hline
\end{tabular}

Sumber :Data diolah, 2017

Data pada table 12 diketahui nilai tolerance untuk masing-masing variabel bebas lebih besar dari 0,10 dan untuk nilai VIF kurang dari 10. Model yang digunakan tidak menggandung gejala multikolinearitas.

Tabel 13

Hasil Uji Heteroskedastisitas

\begin{tabular}{clcc}
\hline \multirow{2}{*}{ No } & \multirow{2}{*}{ Variabel Bebas } & PT. BPR Mertha Sedana & PT. BPR Mas Giri Wangi \\
\cline { 3 - 4 } & & Sig. t & Sig t. \\
\hline 1. & Bukti Fisik & 0,880 & 0,214 \\
2. & Keandalan & 0,500 & 0,056 \\
3. & Daya Tanggap & 1,000 & 0,105 \\
4. & Jaminan & 0,258 & 0,608 \\
5. & Empati & 0,695 & 0,951 \\
\hline
\end{tabular}

Sumber :Data diolah, 2017

Hasil uji heteroskedastisitas PT. BPR Mertha Sedana dan PT. BPR Giri Wangi disajikan pada Table 13. menunjukkan tingkat signifikansi setiap variabel bebas diatas 0,05 sehingga dapat disimpulkan bahwa model regresi terbebas dari heteroskedastisitas.

Tabel 14.

Hasil Uji Normalitas

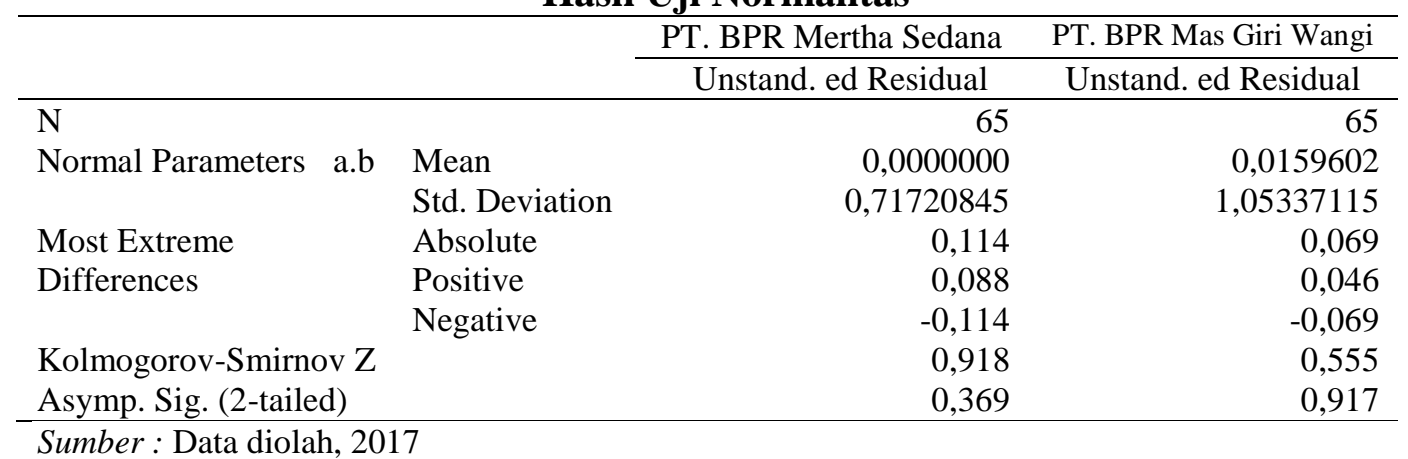


Data pada Tabel 14. diketahui nilai Asymp.sig sebesar 0,369 $>\alpha=0,05$ pada PT. BPR. Mertha Sedana. Sedangkan pada PT. BPR. Mas Giri Wangi menunjukkan bahwa nilai Asymp.sig sebesar 0,917 $>\alpha=0,05$. Sehingga dapat disimpulkan bahwa kedua data hasil uji normalitas pada PT. BPR. Mertha Sedana dan PT. BPR. Mas Giri Wangi berdistribusi dengan normal.

Data pada table 10, menungjukan hasil $\mathrm{Uji} \mathrm{T}$ pada pengaruh variable kualitas pelayanan terhadap kepuasan nasabah PT. BPR Mertha Sedana. Dari data pada table 10, diketahui nilai sig t semua variable bebas lebih kecil dari 0,05. Dapat disimpulkan bahwa bukti fisik, keandalan, daya tanggap, jaminan, dan empati secara parsial berpengaruh signifikan terhadap kepuasan nasabah PT. BPR. Mertha Sedana. Sehingga, $\mathrm{H}_{0}$ ditolak dan $\mathrm{H}_{1}$ diterima.

Data pada table 11, menungjukan hasil $\mathrm{Uji} \mathrm{T}$ pada pengaruh variable kualitas pelayanan terhadap kepuasan nasabah PT. BPR Mas Giri Wangi. Dari data pada table 10, diketahui nilai sig t semua variable bebas lebih kecil dari 0,05. Dapat disimpulkan bahwa bukti fisik, keandalan, daya tanggap, jaminan, dan empati secara parsial berpengaruh signifikan terhadap kepuasan nasabah PT. BPR. Mertha Sedana. Sehingga, $\mathrm{H}_{0}$ ditolak dan $\mathrm{H}_{1}$ diterima.

Berdasarkan hasil analisis Standardized Coefficients Beta yang dapat dilihat dari hasil olahan data dengan menggunakan program SPSS version 15.0, dapat diketahui bahwa variabel empati merupakan variabel yang berpengaruh dominan terhadap kepuasan nasabah pada PT. BPR. Mertha Sedana. Hal tersebut dapat dilihat dari nilai standardized coefficient beta dengan nilai variabel empati yaitu 
sebesar 0,252. Hal ini berarti, nasabah PT. BPR. Mertha Sedana lebih tergantung pada empati terhadap kepuasan nasabah PT. BPR. Mertha Sedana.

Berdasarkan hasil analisis Standardized Coefficients Beta yang dapat dilihat dari hasil olahan data dengan menggunakan program SPSS version 15.0, dapat diketahui bahwa variabel keandalan merupakan variabel yang berpengaruh dominan terhadap kepuasan nasabah pada PT. BPR. Mas Giri Wangi. Hal tersebut dapat dilihat dari nilai standardized coefficient beta dengan nilai variabel keandalan yaitu sebesar 0,230. Hal ini berarti, nasabah PT. BPR. Mas Giri Wangi lebih tergantung pada keandalan terhadap kepuasan nasabah PT. BPR. Mas Giri Wangi.

Berdasarkan hasil pengujian hipotesis menunjukkan variabel bukti fisik, keandalan, daya tanggap, jaminan dan empati berpengaruh terhadap variabel kepuasan nasabah baik nasabah PT. BPR. Mertha Sedana dan PT. BPR. Mas Giri Wangi. Pada penelitain yang dilakukan di PT. BPR. Mertha Sedana menemukan bahwa analisis variabel bebas dari kualitas pelayanan yang terdiri dari bukti fisik, keandalan, daya tanggap, jaminan, dan empati yang memiliki pengaruh dominan terhadap kepuasan nasabah PT. BPR. Mertha Sedana adalah variabel empati,. Sedangkan pada penelitian di PT. BPR. Mas Giri Wangi menemukan bahwa analisis variabel bebas dari kualitas pelayanan yang terdiri dari bukti fisik, keandalan, daya tanggap, jaminan dan empati yang memiliki pengaruh dominan terhadap kepuasan nasabah PT. BPR. Mas Giri Wangi adalah variabel keandalan. 


\section{SIMPULAN DAN SARAN}

Berdasarkan hasil dari penelitian terkait dengan hasil analisis pada bab sebelumnya maka simpulan yang diperoleh sebagai berikut:Kualitas pelayanan yang terdiri dari bukti fisik, keandalan, daya tanggap, jaminan dan empati berpengaruh positif dan signifikan terhadap kepuasan nasabah baik pada nasabah PT. BPR. Mertha Sedana dan PT. BPR. Mas Giri Wangi.

Variabel dominan pada kualitas pelayanan yang memiliki pengaruh dominan terhadap kepuasan nasabah pada PT. BPR. Mertha Sedana adalah empati, sedangkan variabel dominan pada kualitas pelayanan yang memiliki pengaruh dominan terhadap kepuasan nasabah PT. BPR. Mas Giri Wangi adalah variabel keandalan.

Berdasarkan simpulan diatas, adapun saran yang dapat diberikan berdasarkan hasil penelitian adalah sebagai berikut:Kepada komisaris, PT. BPR. Mertha Sedana dan PT. BPR. Mas Giri Wangi memiliki keunggulan yang berbeda didalam pemenuhan kepuasan nasabah melalui kualitas pelayanan. Untuk PT. BPR. Mertha Sedana seharusnya lebih meningkatkan variabel bukti fisik karena memiliki nilai yang paling kecil diantara variabel lainnya. Sedangkan pada PT. BPR. Mas Giri Wangi seharusnya mampu meningkatkan variabel daya tanggap karena memiliki nilai paling kecil diantara semua variabel.

Manajemen PT. BPR. Mertha Sedana dan manajemen PT. BPR. Mas Giri Wangi harus lebih mengetahui secara spesifik kebutuhan dan keinginan nasabah. Dengan meningkatkan kualitas pelayanan (bukti fisik, keandalan, daya tanggap, 
jaminan dan empati) akan mampu meningkatkan kepuasan nasabah sehingga nasabah akan melakukan kunjungan kembali dan loyal terhadap perusahaan.

Manajemen PT. BPR. Mertha Sedana dan manajemen PT. BPR. Mas Giri Wangi juga harus memperhatikan karyawannya, agar karyawan memiliki kemampuan yang lebih baik didalam melayani nasabah kedua BPR. Manajemen PT. BPR. Mertha Sedana dan PT. BPR. Mas Giri Wangi juga harus melakukan pendidikan dan pelatihan dalam upaya peningkatan kemampuan yang dimiliki setiap karyawannya, agar karyawan mampu melayani nasabahnya lebih baik lagi.

\section{REFERENSI}

Akbar, M.M., and Parvez, N. 2009. Impact of Services Quality, Trust, and Customer Satisfaction on Customer Loyalty, ABAC Journal, 29 (1), pp. 2438 .

Al-Rousan, Ramzi, M., and Mohamed, B. 2010. Customer Loyalty and the Impacts of Service Quality: The Case of Five Star Hotels in Jordan International, Journal of Business and Economic Sciences, (5), pp. 202-208.

Anggabrata, Dewa Made Wisnu. 2014. Pengaruh Kualitas Pelayanan Terhadap Kepuasan Nasabah Pada PT BPR Balidana Niaga Denpasar. Skripsi Fakultas Ekonomi Udayana.

Anselmsson, Johan ,et al. 2014. A Comparison Of Customer Perceived Service Quality In Discount Versus Traditional Grocery Stores. An examination of service quality measurement scales in a Swedish context. Internationa Journal of Quality and Service Sciences, 6(4). pp.369-386.

Apriani Munica. 2011. Analisis Pengaruh Fasilitas, Kualitas Pelayanan, dan Kepuasan Pelanggan Terhadap Minat Mereferensikan. (Studi Kasus Pada Konsumen Jasa Pelayanan Cuci Sepeda Motor dan Mobil Star Clean di Semarang) Skripsi Fakultas Ekonomi Universitas Diponogoro Semarang 2011

Aryani, D , dan Febriana Rosita. 2010. Pengaruh Kualitas Layanan terhadap Kepuasan Pelanggan dalam Membentuk Loyalitas Pelanggan. Bisnis \&Birokrasi, Jurnal Ilmu Administrasi dan Organisasi. 17(2).h. 114-126. 
Ashfaq Ahmad, Iqbal Saif and Nadeem Safwan. 2010. An empirical investigation of Islamic banking in Pakistan based on perception of service quality. African Journal of Business Management, 4(6), pp. 1185-1193.

Aypar Uslu dan Beril Sipahi, 2010. Menilai Kualitas Jasa Internet Banking : ERoute atas kesetiaan. Journal University Marmara, Turki.

Banerjee, N Dr, and Santosh Sah. 2012. A Comparative Study of Customer's Perceptions of Service Quality Dimensions between Public and Private Banks in India. International Journal of Business Administration .3(5). pp.33-44.

Bedi, M. 2010. An Integrated Framework for Service Quality, Customer Satisfaction and Behavioral Responses in Indian Banking Industry- a Comparison of Public and Private, Journal of Services Research,10(1), pp. 157-172.

Berry, L. L.; Zeithaml, V. A. \&Parasuraman, A. 1985.Quality Counts in Services, Tools. Business Horizon, pp 44-52.

Berry, L. L.; Parasuraman, A. and Zeithaml, V. A. 1988. The Service Quality Puzzle. Business Horizon,pp 35-43.

Choudhury, K. 2008. Service Quality: Insights from The Indian Banking Scenario, Australasian Marketing Journal, 16(1), pp. 48-61.

Fatih, HZ, et al. 2010. Service Quality And Determinants Of Customer Satisfaction In Hospitals Turkish Experience. International Business \& Economics Research Journal. 9(5). pp. 51-58.

Ferdinand. 2002. Strctural equation modeling (SEM)dalam Penelitian Manajemen. Program Magister Manajemen Universitas Diponegoro. Badan Penerbit Universitas Diponegoro.

Gerrard, Philip, Cunningham, Bart, 2001. Bank service quality: A comparison between a publicly quoted bank and government bank in Singapore.Journal of Financial Services Marketing

Ghozali, Imam. 2008. Model Persamaan Struktural Berbasis Komponen, Cetakan Pertama. Semarang : Badan Penerbit Universitas Diponegoro.

Ghozali, Imam. 2012. Aplikasi Analisis Multivariate dengan Program IBM SPSS 20. Semarang : BP UNDIP.

Gunadi Agus, 2002. Analisis Pengaruh Kualitas Pelayanan Terhadap Kepuasan Nasabah Pada PT. BPR Pedungan Denpasar. Skripsi Fakultas Ekonomi Udayana. 
Hadiati Sri, 2003. Analisis Pengaruh Kualitas Pelayanan Terhadap Kepuasan Nasabah Bank Widyana Malang. Jurnal Universitas Gajayana Malang.

Haque Imamul. 2011. Service Quality in Retail Banking- A Comparative Study between Public Sector Banks \& Private Sector Banks.International Journal of Management and Innovation Volume 3 Issue 2.

Irmawati Grace Sally, IGA. 2012. Analisis Kualitas Layanan dan Kepuasan Nasabah PT. CIMB NIAGA Cabang Denpasar (Studi Komparasi Sebelum dan Setelah Merger). Jurnal Manajemen, Strategi Bisnis dan Kewirausahaan Vol.1, No.2.Hal.140-158.

Isibor, Felix O,and Onowe Edith Odia. 2014. Comparative Study of Service Quality in Nigerian Restaurant and Transport Business Organisations. International Journal of Business and Management. 9.(4). pp.153-159.

Jaman Adi Putra, I Wayan. 2009. Pengaruh Kualitas Pelayanan terhadap Kinerja Kerelasian Nasabah, Jurnal Ekonomi Bisnis, 2, hal. 151-160.

Koestanto Hari Tri. 2014. Pengaruh Kualitas Pelayanan Terhadap Pelanggan Pada Bank Jatim Cabang Klampis Surabaya. Jurnal Ilmu \& Riset Manajemen, 3(10).hal 1-10

Kotler, Philip, 2002. Manajemen Pemasaran, Jilid 1, Edisi Milenium, Jakarta,Prehallindo.

Kusuma, Gst Ayu Putu Ratih Dewi, 2014. Pengaruh Kualitas Pelayanan Terhadap Kepuasan dan Loyalitas Nasabah PT. BPR Hoki di Kabupaten Tabanan.

Lymperopoulos, C., Chaniotakis, I.E., and Soureli, M. 2006.The Importance of Service Quality in Bank Selection for Mortgage Loans, Managing Service Quality, 16(4), pp. 365-379.

Madhukant Dr. and K. Pate, 2011. Service Quality and Bank Performance: A Comparative Analysis Of Public and Private Banks In The State Of Gujarat.Summer Internship Society, 2(2),pp.1-22

Malik, Garima.Dr. 2012. A Comparative Study on the Service Quality and Customer Satisfaction among Private and Public Banks in India. Pacific Busines Review International.4(3). pp. 51-64.

Melissa. 2010. Pengaruh Retali Service dan Store Image terhadap Kepuasan dan Loyalitas Pelanggan di Pepito Supermarket Kuta-Bali, Tesis, Program Studi Magister Manajemen Universitas Udayana, Denpasar.

Metayunika Vidya. 2013. Analisis Pengaruh Kualitas Pelayanan (Tangible, Reliability, Responsivenes, Assurance, dan Emphaty) Terhadap Kepuasan Konsumen (Studi pada Dealer Mitsubishi PT Bumen Redja Abadi 
Semarang) Skripsi Program Sarjana (S1) pada Program Sarjana Fakultas Ekonomika dan Bisnis Universitas Diponegoro.

Mishra, U.S., Saho, K.K., Mishra, S., and Patra, S.K. 2010. Services Quality Assessment in Banking Industry of India : A Comparative Study Between Public and Private Sectors, European Journal of Social Sciences, 16(4), pp. 653-669.

Nalim, 2015. Analisis Komparatif dan Eksploratif Terhadap Kualitas Pelayanan Bank Syariah dan Bank Konvensional di Kota Pekalongan. Jurnal Hukum Islam, 13(2), hal.1-20

Parasuraman, A., Zeithaml, V. A., and Berry, L. L. 1985. "A Conceptual-Model of Service Quality and Its Implications for Future-Research". Journal of Marketing, 49(4),pp. 41-50.

Parasuraman, A., Zeithaml, V. A., \& Berry, L. L. 1988. "Servqual - a MultipleItem Scale for Measuring Consumer Perceptions of Service Quality". Journal of Retailing, 64(1),pp. 12-40.

Patel K., Dr. Madhukant. 2011. Service Quality and Bank Performance : A Comparative Analysis Of Public and Private Banks In the State Of Gujarat. International Journal of Management Prudence, 3(2), pp. 1-28

Pawitan,G , dan Maria, W. 2011. Perbandingan kualitas layanan berdasarkan kategori restoran : Studi Kasus di BadungBali. Jurnal Administrasi Bisnis, 7(1) hal.20-33.

Presbury, Rayka, Anneke Fitzgerald and Ross Chapman. 2005. Impediments ToImprovements In Service Quality In Luxury Hotels, Managing Service Quality, 15(4) pp. 357-373.

Regan Lam dan Hing Po Lo, 2009. Investigasi The Driver Dari Kepuasan Perbankan UKM Di Hong Kong. Journal City University of Hong Kong

Roslina, YN, dan Ester Manik. 2015. Analisis Komparatif Pelayanan Akademik pada Fakultas Ekonomi dan Fakultas ISIP Universitas Jendral Ahmad Yani. Jurnal Ekonomi, Bisnis, \& Entrepreneurship.9(2), hal 116-135.

Setyari, Ni Putu Wiwin. 2007. Posisi Fungsi Intermediasi Bank Umum dan BPRdi Bali: Sebuah Kajian Kompharatif, Buletin Studi Ekonomi, 12(2), hal. 122133.

Siddiqi, K.O. 2011. Between Service Quality Attributes, Customer Satisfaction and Customer Loyalty in the Retail Banking Sector in Bangladesh,International Journal of Business and Management, 6(3), pp. 12 -36 . 
Singh, Surabhi, and Renu Arora. 2011. A Comparative Study of Banking Services and Customer Satisfaction in Public, Private and Foreign Banks. Economics Jurnal. 2(1) pp. 45-56.

Sugiyono. 2014. Metode Penelitian Bisnis (Pendekatan Kuantitatif, Kualitatif, dan $R \& D$ ). Bandung : Alfabeta.

Suharso dan Sulistyawati Arie. 2012. Pengaruh Kualitas Pelayanan Terhadap Kepuasan Pelanggan Restoran Indus Ubud - Gianyar. Skripsi Sarjana Jurusan Manajemen Fakultas Ekonomi dan Bisnis Universitas Udayana.

Sumani. 2008. Pengaruh Kualitas Produk Terhadap Kepuasan Pelanggan Kartu Prabayar IM3 : Studi Kasus Pada Mahasiswa Program Studi Manajemen di Mojokerto. Jurnal Eksekutif, 5(1), h 26-37.

Sunarto, 2006. Analisis Faktor-faktor yang mempengaruhi kepuasan pelanggan dan dampaknya terhadap keunggulan bersaing (studi pada tabungan Britama BRI Kanca Kendal). Jurnal Fakultas Ekonomi Universitas Diponegoro Semarang.

Taap Amat Manshor and Siong Choy Chong.2011.Measuring Service Quality of Conventional and Islamic Banks A Comparative Analysis.International Journal of Quality Science

Tanushree Gaura Nautiyal. 2016. A Comparative Study Of Customer Satisfaction in Public and Private Sector Bank Using SERVQUAL Model.Journal of Management \& IT-Sanchayan, 5(1).pp: 1-18

Tjiptono, 2006. Manajemen Jasa. Yogyakarta: Andy Offset.

Undang-undang No. 10 Tahun 1998 tentang Perbankan

Wirawan Nata, 2002. Cara Mudah Memahami Statistik 2 (Statistik Inferensia). Untuk Ekonomi dan Bisnis. Edisi 2. Denpasar : Keraras Emas.

Yapa S.T.W.S. and K.M. Hasara,. (2013) Bank Service Quality In Sri Lanka : A Comparative Study Between Public and Private Sectors.Proceedings of $3^{\text {rd }}$ Asia-Pacific Business Research Conference 25 - 26 February 2013, Kuala Lumpur, Malaysia,

Yarimoglu, EK . 2014. A Review on Dimensions of Service Quality Models. Journal of Marketing Management.2(2) pp. 80-92.

Yonggui W, Lo Hing-Po, Yang Yongheng. 2004. An Integrated Framework For Service Quality, Customer Value, Satisfaction. Evidance From China's Telecomunication Industry. Journal Service Quality. Kluwer Academic Publisher. Nedherlands. 